\title{
Designing a Comprehensive Project for a Junior-level Multidisciplinary En- gineering Design Course
}

\section{Mrs. Amanda C. Rutherford, Montana State University}

Amanda Rutherford is a teaching faculty member at Montana State University. She is the lead curriculum coordinator for the Junior Multidisciplinary Engineering Design Course, which all students in the College of Engineering must take, as well as the faculty director of the MSU Makerspace. Prior to coming to MSU as a faculty member, she earned a BS in Civil Engineering (MSU), MS in Engineering Mechanics (Virginia Tech) and worked as a research engineer at Los Alamos National Laboratory.

\section{Mr. Brad Thomas Stanton, Montana State University \\ Mrs. Staci Turoski, Mrs. Elizabeth B Varnes, Montana State University}

After earning a BSEE from Clemson University, I worked for the Department of Defense for 11 years. During that time I earned a MS in Engineering Management from Old Dominion University. My next assignment was with Scientific Research Corporation, a defense contractor, where I worked until December 2016. In January 2017, I joined Montana State University serving as an instructor and Special Assistant to the Dean of the College of Engineering. 
Designing a Comprehensive Project for a

Junior Level Multidisciplinary Engineering Design Course 


\section{Introduction}

This paper provides an overview of a major revision of a multidisciplinary engineering design (multi-d design) course, which is required for all engineering programs at Montana State University and junior level engineering students. The changes to the multi-d Design course have achieved a number of preset goals. The course introduces engineering students to topics such as the design process, creative design, project management, teamwork, and technical leadership while highlighting the skills needed to work in a multi-disciplinary environment.

The course is offered in both fall and spring semesters in 6 to 8 sections of 40-50 students each. Each of the four course instructors teaches and mentors design groups in their own section(s) and divide the classes up into student groups of 4-5 students. Our instructional team consists completely of teaching professionals (non-tenure track faculty) with a variety of backgrounds and industry experience. In order to make mentoring 10 to 20 teams tractable, all students teams complete the same design challenge. Creating a "good" design challenge is crucial, as the course does more than simply teach the design process (see Figure 1). Teaming and leadership skills, project management, ethics, and technical communication are important outcomes for the course. All of these "Soft-skill" areas are made more palatable to our students if our design challenge is engaging and fun.

With eleven different engineering disciplines (mechanical engineering, mechanical engineering technology, electrical engineering, computer engineering, civil engineering, chemical engineering, bioengineering, industrial engineering, financial engineering, construction engineering technology, and computer science) to cover, creating a design challenge that engages all students has been a work in progress. However, big strides were made in the last year with the introduction of the "Cat's Conundrum" design challenge. In this paper, we will discuss how we transformed one instructor's interest and enthusiasm for RC cars into a multidisciplinary design project that students are fully engaging with.



Figure 1: Topics of instruction in our multi-disciplinary design course. 


\section{Background}

The course was established in 2009 to support ABET [1] requirements of providing a multi-d design experience for Montana State University students. The overarching objectives of the course were to provide an understanding of the engineering design process and require students to build a design within some given parameters, while working on teams across engineering disciplines.

In the past, two different approaches were used to define projects:

1. Teach design process in the context of a community-centered, discipline-neutral project. The operating hypothesis for this path is that while it might be difficult to design a project that includes technical elements from all eleven engineering disciplines, complete discipline inclusion might not be necessary if a project topic is selected that ignites passionate interest by the students. Design process could be taught in a somewhat discipline neutral fashion, while still having a "real" project for the students to work on. This type of "empathetic" design project tends to be more user-centered; students must understand the needs and goals of a variety of stakeholder groups.

2. Teach design process by defining a technical project that attempts to contain elements from as many of the eleven engineering disciplines as possible, so that each student feels that there is a portion of the problem that is relevant to them. Function identification and system integration become very important.

For a few years, both philosophies were implemented with two different "mini- projects" in one semester. A community-based problem, sourced from local non-profits and campus entities, formed the first design challenge. Solutions for this were primarily paper solutions only. However, students were given opportunities to interact with stakeholders, encouraged to observe actual locations, and/or experience problematic issues themselves. Example design challenges included re-routing of the town bus system to increase efficiency, redesign of bridges in a town trail system, redesign of a trailhead parking lot, increase in campus bike friendliness, and revamp of dorm move-out procedures to generate less waste. Student solutions were then handed over to the entities that had proposed the problems, and in some cases those solutions were eventually implemented.

The second project of the semester was tailored to be more technical in nature. After a few semesters, we determined that having two projects in one, 16-week semester was too much responsibility for the students and the instructor. Once the technical design challenge was sufficiently developed, the community design challenge was eliminated.

Development of the technical design challenge took time, as constraints were many. As aforementioned, as many of the eleven engineering majors as possible needed to be challenged by the project. There was a strong desire for a project that would actually be "built" (as opposed to a paper-only project), but constraints on where students could actually do this made project definition even more difficult. Initially, students were told to "use your garage, good luck". This limitation was difficult for many students with no access to facilities other than their dormitory. While our College of Engineering has extensive machine shops and Montana State 
University at large has some woodworking facilities, these are largely not available to juniorlevel engineering students. Because students would be building at home, the project needed to utilize non-toxic materials which limited scope and interest to some extent. Additionally, the course was executed with a rotating instructional staff that changed significantly each semester, so the project had to be easily communicated to each new round of instructors.

As a result of these listed constraints, the "Desalinator" challenge was developed. This multi-d design project involved the utilization of a super absorbent polymer (SAP) bead/powder to remove $\mathrm{NaCl}$ from water. This project was based on work by J. Hoepfner [2] that proposed use of SAP in desalinating activities. This mulit-d project was challenging for some engineering disciplines but not all. The overall desalinator project did not engage the students well for a variety of reasons. First, the project had no actual real-world application as many of the health standards for providing potable water had to be ignored. Additionally, results were not exceptionally dynamic (changes in salinity were relatively small). Thirdly, because of the time constraint of one semester, there was not enough time to produce multiple prototyping rounds. Lastly, the project was difficult to explain and highlight. Students desiring to showcase their coursework did not find the multi-d project worth mentioning.

\section{The Need for Change}

Discussions for revamping the project began to occur following the Spring 2017 semester. The instructor team of 4 was projected to be consistent through the AY 2018 and had developed into an effective and communicative team with each instructor being fully vested in multi-d design course delivery. This team realized that the timing for implementation of a dramatic change in the project was opportune because of the member expertise, available time for development, consistent involvement, and support from various faculty to improve student learning of engineering design within a multi-d engineering team arrangement. Additionally, the Makerspace facility was fully established to support the multi-d design course but with flexibility to host students from across campus maintaining its open-to-all makerspace mission. The Makerspace offered an exceptional location for students to develop a multi-d design and for hosting team demonstrations. The effort for "redesigning" the multi-d design course began with the resources in place to launch a major improvement.

In starting to investigate a redesign of the project, several considerations needed to be addressed. First, the course objectives were not to be changed and needed to continue to meet ABET requirements. A list of goals for an improvement in the project was generated and included the following:

- Focus on conducting one (versus two) technical projects with multiple prototypes developed in a single semester;

- Provide a project that is technically challenging for multiple disciplines;

- Provide a project that could be accomplished with a variety of team disciplines (due to registration issues with multiple classes, the makeup of classes by discipline can change every semester. Sometimes when establishing teams of 4-5 members, registration in the class may slightly vary. The registrar does work with the instructor team to distribute 
discipline majors amongst classes but there is not an exact numeration of disciplines at this point);

- Allow for brainstorming to occur during the development of a design;

- Establish a clear indication of student project success;

- Develop a multi-faceted engineering project which scaffolds the students design experience in a way that prepares them for capstone, while giving them experience that could bolster their future employment opportunities.

- Develop a project that would engage student interest and possibly provide for friendly competition. The project should be "fun" even when requiring hard work;

- Select a project that would be palatable to overall faculty within the college of engineering;

- Maintain a budget affordable for students;

- Utilize existing resources available (i.e., Makerspace); and

- Develop curriculum that scaffolds the students through the design process, and also includes elements of project management, teaming and other "soft skills".

With these goals in the forefront, the instructor team began to consider project ideas. However, one instructor had a particular expertise in Remote Controlled Vehicles (RCVs). After several discussions of possible new projects, brainstorming centered around RCVs took off and eventually became the lynchpin of the new multi-d project.

\section{Remote Controlled Vehicle (RCV) Introduction}

The next step after deciding to explore the change of the multi-d engineering design project to a RCV challenge was to define the project to ensure ABET objectives would be completely met, map project details to the learning outcomes established by the college of engineering for the junior level engineering multi-d course, solve the problems experienced with previous iterations of the course, and offer a unique project that would engage student interest, excitement, and passion because of the learning opportunity and pulling a variety of resources together for a common and fun goal. With discussions starting in June 2017 and Fall semester commencing August 2017, the time constraint for development was a bit daunting. The instructional team spent time brainstorming how an RCV project could be implemented. From this, the idea for the "Cat's Conundrum" was established and a list of items for development was made:

- Provision for each of the 11 engineering disciplines to have viable responsibility and grow their engineering design skill;

- Clearly defined discipline specific requirements and documentation developed for students to understand their particular role;

- Clear description of the engineering design process [3], [4], [5] and how it maps with the RCV development project;

- Demonstration track for the RCVs to run

- A streamlined method that would enable 45-88 student groups to demonstrate their RCV design project at the end of the semester. 
- A plan to house the track within the existing Makerspace facility without taking up an "unreasonable" amount of space.

- Rules for RCV demonstrations;

- Grading rubrics for each of the deliverables as they pertain to each unique engineering discipline;

- Methods for incorporating soft skills (i.e., project management, oral communication, documentation development, portfolio development);

- Ethics studies incorporation; and

- Resources for students (Makerspace, 3-D printing, parts ordering, sample RCVs, references for information gathering about RCVs and other parts of the project once defined).

Each of the items listed was addressed throughout the course of the 2017 summer months. First learning outcomes for the students were defined. This was done by using ABET outcomes as a constraint, but also by asking ourselves "What should a student who has finished multi-d design know?" The "student friendly" outcomes are listed:

- Extend the student comfort zone in engineering design through struggle with the unknown (components of the RCV must be developed versus purchasing a commercial off-the-shelf RCV) [6]

- Become a self-guided problem solver

- Experience the design process and be able to converse thoughtfully about alternate design methodologies

- Practice leadership, communication, and project management in a multi-d setting

- Reduce an open-ended design challenge to manageable, quantifiable problems that allow math and reason to guide a student's decision making

- Develop prototyping skills (and have fun making stuff)

- Recognize that integration of different prototype subsystems takes planning and communication between disciplines in order to be successful.

- Employ discipline specific hard skills to solve real problems

- Develop a student's resume through construction of a portfolio page highlighting the student's part of the "Cat's Conundrum"

Logistical concerns such as devising a track for vehicles to navigate also had to be addressed. A modular track was developed in duplicate (Figure 2). 


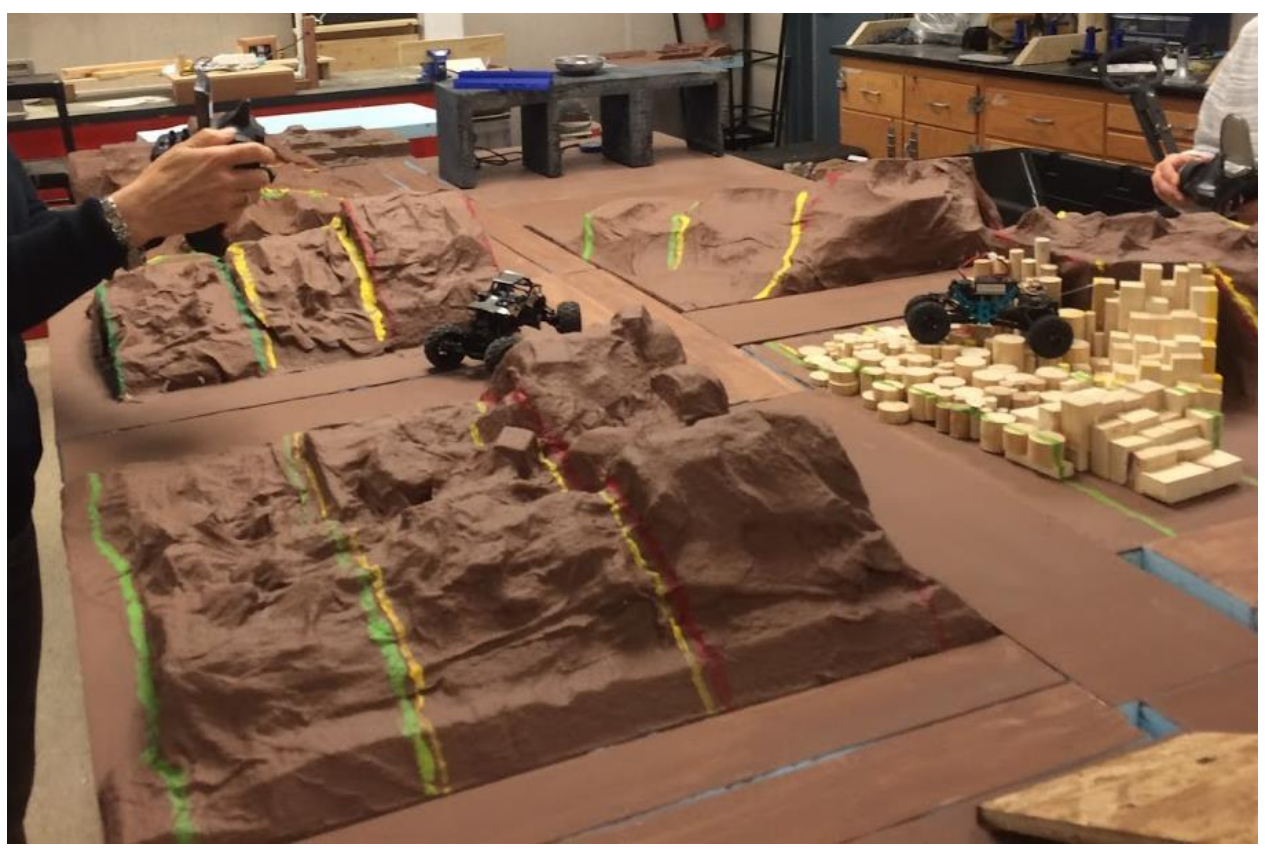

Figure 2: One of the "Cat's Conundrum" tracks constructed for $1 / 24$ scale RCVs

Modularity meant that the track could be taken apart and stored in a compact fashion in the Makerspace. Duplicate development meant that we would be able to run two demonstrations simultaneously, hopefully cutting in half the time required for the demonstration process. Each of the two tracks consists of eight 2'x2' elements separated by spacers. Model railroading landscape terrain techniques were used to construct the terrain for $1 / 24$ scale RCVs. The use of a modular track gave flexibility for students to develop track elements themselves. This solved the other half of the discipline engagement problem. While ME/T, EE, CPE and CS students are largely working towards developing the RCV itself, CE/T, ChE, BE, IMSE and FE students are designing track elements or optimizing the path through. Now, every discipline could be represented by design problems central to their knowledge at this point in the educational tenure. These topics are more thoroughly discussed in the section on course content. Areas of design responsibility are articulated in Table 1 . 
Table 1: Discipline Specific Design and Project Responsibilities

\begin{tabular}{|l|l|}
\hline Engineering Discipline & Responsibility with Design and Project \\
\hline $\begin{array}{l}\text { Mechanical Engineer/Mechanical } \\
\text { Engineering Technology }\end{array}$ & Design of the mechanical body of the RCV \\
\hline $\begin{array}{l}\text { Electrical Engineering, Computer } \\
\text { Engineering }\end{array}$ & $\begin{array}{l}\text { Design of the circuitry necessary to remotely } \\
\text { control the vehicle }\end{array}$ \\
\hline Computer Science & $\begin{array}{l}\text { Code a user interface for a phone or computer } \\
\text { that controls the vehicle }\end{array}$ \\
\hline Chemical Engineering, BioEngineering & $\begin{array}{l}\text { Design of a pump system that facilitates easy } \\
\text { passage of the RCV through a "swamp" } \\
\text { floating bridge which floats to an optimal } \\
\text { level based on a pumping system challenge) }\end{array}$ \\
\hline Civil Engineering, Construction Engineering & $\begin{array}{l}\text { Design and construction of a scaled banked } \\
\text { turn for the RCV to navigate with additional } \\
\text { teaming responsibilities for project } \\
\text { management of the design process. }\end{array}$ \\
\hline Industrial Engineering & $\begin{array}{l}\text { Design an optimization problem for } \\
\text { navigating the "Cat's Conundrum" track with } \\
\text { additional teaming responsibilities for project } \\
\text { management of the design process }\end{array}$ \\
\hline
\end{tabular}

Knowing that variations in the engineering discipline composition of teams is a reality of the class, we needed to ensure that variations to the project requirements could be made relatively easily. Design requirements were formulated with this in mind and Table 2 shows how differing make ups of team disciplines could work in each team. 
Table 2. Discipline Specific Design Requirements Based on Team Composition

\begin{tabular}{|c|c|}
\hline Missing Deiscipline in a Group & Responsibility with Design and Project \\
\hline $\begin{array}{l}\text { Mechanical Engineer/Mechanical } \\
\text { Engineering Techology }\end{array}$ & $\begin{array}{l}\text { Students may purchase any } 1 / 24 \text { RC Rock } \\
\text { Crawler Kit (but cannot use the electronics). } \\
\text { The Makerspace has a limited supply of } \\
\text { Basher Rocksta kits available that may } \\
\text { require students to purchase motors. }\end{array}$ \\
\hline $\begin{array}{l}\text { Electrical Engineering, Computer } \\
\text { Engineering, or Computer Science }\end{array}$ & $\begin{array}{l}\text { Students can purchase a commercial RC } \\
\text { Transmitter, Receiver, Electronic Speed } \\
\text { Control (ESC), Motor, Servo, and Battery. }\end{array}$ \\
\hline $\begin{array}{l}\text { Civil Engineer, Construction Engineering } \\
\text { Technology }\end{array}$ & $\begin{array}{l}\text { Students do not have to construct "The } \\
\text { Embankment" challenge. }\end{array}$ \\
\hline Construction Engineering Technology & $\begin{array}{l}\text { Students will be allowed to reverse engineer } \\
\text { your Gantt charts. }\end{array}$ \\
\hline Chemical Engineer/Biological Engineer & $\begin{array}{l}\text { Students do not have to attempt "The } \\
\text { Swamp". }\end{array}$ \\
\hline Industrial Engineering & $\begin{array}{l}\text { Students will not be held accountable } \\
\text { for predetermining the vehicle path based } \\
\text { on an optimization of speed and points. }\end{array}$ \\
\hline If student groups have: & Responsibility \\
\hline $\begin{array}{l}\text { 1) Computer Scientist, Electrical } \\
\text { Engineer } \\
\text { 2) Computer Scientist, Computer } \\
\text { Engineer }\end{array}$ & $\begin{array}{l}\text { GUI + Electronics (NO commercial RC ESC, } \\
\text { Transmitter, Receiver allowed. Students must } \\
\text { write your own GUI control). }\end{array}$ \\
\hline $\begin{array}{l}\text { Any Combination of Computer Engineer and } \\
\text { Electrical Engineer including lone Computer } \\
\text { Engineer or Electrical Engineer }\end{array}$ & $\begin{array}{l}\text { NO GUI + Electronics (NO commercial RC } \\
\text { ESC, Transmitter, Receiver allowed. } \\
\text { Students DO NOT need to write a GUI. } \\
\text { Joystick type controller is acceptable. } \\
\text { Consider using Radio Frequency_-RF) }\end{array}$ \\
\hline One or more Computer Scientists & $\begin{array}{l}\text { GUI+Commercial RC ESC. By allowing the } \\
\text { use of a commercial ESC, much of the wiring } \\
\text { complexity is removed. A suggested wiring } \\
\text { diagram is provided in the CpS course } \\
\text { document. No RC transmitter or receiver } \\
\text { allowed unless controlled by a GUI that you } \\
\text { write. }\end{array}$ \\
\hline
\end{tabular}

\section{Discipline Specific Knowledge Required for "Cat's Conundrum"}

As noted previously, and as seen in the literature, designing a challenge that engages disciplines typically involved in artifact design (ME/T, EE, CpE and CS) is relatively low hanging fruit. However, to design a project that also engages those disciplines who either design largely on paper $(\mathrm{CE}, \mathrm{ChE})$ or are designers of processes (ChE, BE, IE, CET) is significantly more challenging. How to do this? When we hit upon the RCV idea, we did not realize that we likely opened a productive "can of worms," for really any "transportation infrastructure" themed 
project could work in this respect. That is, the artifact focused disciplines could design the vehicle (RCV, quadcopter, submarine, etc.) and the more process/paper-oriented disciplines can focus on designing obstacles that relate to their own disciplines.

In practice, for us, this looks like having the $\mathrm{CE} / \mathrm{T}$ and $\mathrm{ChE} / \mathrm{BE}$ students design track elements (which depend on their discipline specific expertise) that are tailor made for their team's vehicle to score maximum points. The IE/FE students are utilizing linear programming skills to determine optimal path through the course for the vehicle to score maximum points in minimum time. IE/FE and CET students are also charged with becoming project managers for their teams. While this is a specific example of how this has played out for our multidisciplinary design project, with some modification it could be extended to other "transportation infrastructure" projects.

The discipline specific required knowledge areas are:

- Mechanical Engineering/Mechanical Engineering Technology = torque/power calculations

- Electrical Engineering/Computer Engineering = receiver/transmission, electronic speed control, power

- Civil Engineering = friction slip tip, horizontal curve layout

- Construction Engineering Technology = project management, construction practices

- Chemical Engineering/BioEngineering/Civil Engineering with a focus on fluids = Bernoulli's equation, pumps, head losses

- Computer Science = User Interface creation, wireless "packets" of information

- Industrial and Management Systems Engineering/Financial Engineering = project management, linear programming

\section{"Soft Skills" Improvement Concurrent with "Cat's Conundrum" Implementation}

In addition to design process, our junior level multi-discipline design course has also been tasked with teaching/reinforcing a soft skill set identified by faculty, ABET and industry standards as being important for our students to become proficient with. While soft skills were a part of prior incarnations of the class, this aspect has also been strengthened and improved. For example, teaming and leadership are taught formally in five class periods. Students are introduced to the five leadership practices articulated by Posner and Kouzes in A Student Leadership Challenge [7] with accompanying activities for reinforcement. Other soft skill areas that we teach and the ways in which they are addressed are summarized in Table 3. 
Table 3: Soft skills taught in conjunction with "Cat's Conundrum"

\begin{tabular}{|l|l|}
\hline Skill & Curricular Implementation \\
\hline $\begin{array}{l}\text { Teaming and } \\
\text { Leadership in Multi } \\
\text { D teams }\end{array}$ & $\begin{array}{l}\text { Student Leadership Challenge leadership practices, discussion board } \\
\text { deliverables on Brightspace D2L [8] }\end{array}$ \\
\hline $\begin{array}{l}\text { Project Management: } \\
\text { Waterfall }\end{array}$ & Gantt chart populated for design project, revised as project progresses \\
\hline $\begin{array}{l}\text { Project Management: } \\
\text { Agile }\end{array}$ & $\begin{array}{l}\text { Students manage project between milestones using Trello® [9] and } \\
\text { scrum/kanban board style "Backlog - In progress - Complete" }\end{array}$ \\
\hline Oral communication & $\begin{array}{l}\text { Instruction/practice giving elevator pitches, student teams required to } \\
\text { "teach" ethical case studies for ethics portion of the class, student } \\
\text { narrated video required for Prototype 1 milestone }\end{array}$ \\
\hline $\begin{array}{l}\text { Written } \\
\text { Communication }\end{array}$ & $\begin{array}{l}\text { Written deliverables required for every milestone in various formats } \\
\text { ("Progress reports", final design Technical Memo, A3, discussion } \\
\text { board deliverables on Brightspace D2L }\end{array}$ \\
\hline Ethics in Design & $\begin{array}{l}\text { student teams required to teach ethical case studies for ethics portion } \\
\text { of the class, discussion board deliverables on Brightspace D2L }\end{array}$ \\
\hline
\end{tabular}

\section{"Cat's Conundrum" Implementation Fall 2017}

In order to implement the new project into the Fall 2017 course, significant documentation had to be developed relevant to the details of the project. While the bones for doing this existed from prior versions of the class, all of the project specific documentation had to be regenerated.

Careful consideration was given to crafting deliverables that would challenge the students in a variety of areas and expose them to a wide range of technical communication requirements (i.e., oral presentations, videography, discussion posts, technical memorandums, sketches, drawings, Trello ${ }^{\circledR}$ and Gantt chart development, CAD usage, 3-D printing usage, Proof of Concept reports, final design documentation, portfolio page, A-3). Design process steps had to be clearly linked to both individual (discipline specific) and group deliverables. Table 4 shows how design steps are linked to deliverables. 
Table 4: Linking of design process steps to design project (assessable) milestones

\begin{tabular}{|c|c|}
\hline Design Process Step & "Cat's Conundrum" Milestone \\
\hline $\begin{array}{l}\text { Discover (develop enough background } \\
\text { knowledge to define the problem) }\end{array}$ & $\begin{array}{l}\text { Proof of Concept A: Research underpinning } \\
\text { mathematical concepts that relate to the design; } \\
\text { develop bones of mathematical model that will } \\
\text { guide the design; begin a tentative bill of materials } \\
\text { list. Individual and group progress report due. }\end{array}$ \\
\hline $\begin{array}{l}\text { Define (problem statement, functional } \\
\text { diagram, objectives and constraints) }\end{array}$ & $\begin{array}{l}\text { Proof of Concept B: Clearly identify design } \\
\text { functions, objectives and constraints. Begin } \\
\text { populating mathematical model with what you } \\
\text { know, guess at what you don't know; finalize long } \\
\text { order-time bill of materials items with sound } \\
\text { reasoning for choices. Individual and group progress } \\
\text { report due. }\end{array}$ \\
\hline $\begin{array}{l}\text { Ideate (brainstorm, morph charts, Pugh } \\
\text { charts, mock-ups) }\end{array}$ & \multirow{3}{*}{$\begin{array}{l}\text { Prototype 1: Four-minute video detailing test plan } \\
\text { execution, relevance of test results. This is a fully } \\
\text { functioning (though not optimal) prototype. } \\
\text { Individual and group progress report due. } \\
\text { Prototype } 2 \text { ("Cat's Conundrum Course" Run): } \\
\text { Vehicle demonstration on "Cat's Conundrum } \\
\text { Course" (for a competitive score!), A3 document, } \\
\text { and individual and group progress report templates. } \\
\text { This is a refined prototype. Individual and group } \\
\text { progress report due. }\end{array}$} \\
\hline $\begin{array}{l}\text { Prototype (create a comprehensive } \\
\text { prototype for testing) }\end{array}$ & \\
\hline $\begin{array}{l}\text { Test (test your prototype and loop back } \\
\text { to discover) }\end{array}$ & \\
\hline Communicate (design documentation) & $\begin{array}{l}\text { Final Design Documentation: On paper design } \\
\text { detailing cost analysis, market considerations, } \\
\text { design for } x \text {, and FMEA as well as final design } \\
\text { sketches or CAD work. }\end{array}$ \\
\hline
\end{tabular}

As part of the curriculum development, the instructors felt it would be advantageous to have the students provide standardized engineering reporting for the first two major deliverables. These two documents are the Individual Progress Report (IPR) and the Group Progress Report (GPR). The benefit of requiring a standard report is for the students to be exposed to several aspects of design development reporting utilized in industry. For example, a Bill of Materials, Gantt Chart, and Time Expenditure are all required parts of the reports. This has an added benefit to a grading rubric which is more uniform across teams and classes.

For the third deliverable, a 4-minute video is required. Teams are to develop the video to highlight the beginning stages of RCV functionality and the progress of element development and working (i.e., Chemical and Biological Engineers demonstrate their preliminary pumping mechanism). The videos are shown during class times to offer another opportunity for students to glean ideas from others and to hopefully improved their designs. 
The design project itself is half of an individual student's grade. The other half is comprised of quizzes and participation grades (largely assessed with discussion board deliverables on Brightspace D2L.

Another deliverable of sorts is the "Cat's Conundrum" track run demonstration. While students' grades are not directly tied to their track run score, it provides a competitive incentive that many students really engage with. Aside from the required elements (depending on discipline composition of their team), students can choose which elements they want to include in their track run, as each track has twelve elements to choose from (and a complete track is eight tiles).

In addition to gradable portions of the course, the "Cat's Conundrum" rules were established as a means of offering incentives to students for various levels of challenge with the track elements. Elements are designed with differing difficulties not only between the elements themselves but within an element in some cases. Students are provided with a detailed listing of scoring and weighting of the elements they will attempt to traverse during their demonstration. Element weighting can be changed to encourage students to design radically different RCVs from one semester to the next. For example, one of the more difficult tiles is "The Stumper" (Figure 3). A vehicle designed to surmount The Stumper would be quite different from a vehicle optimized for another difficult element called "The Mixing Bowl" (Figure 4).

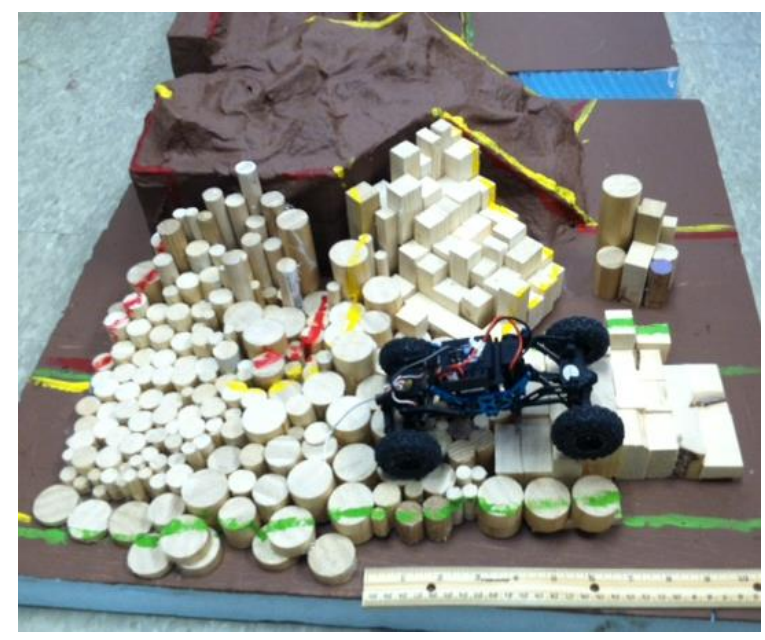

Figure 3: The Stumper 


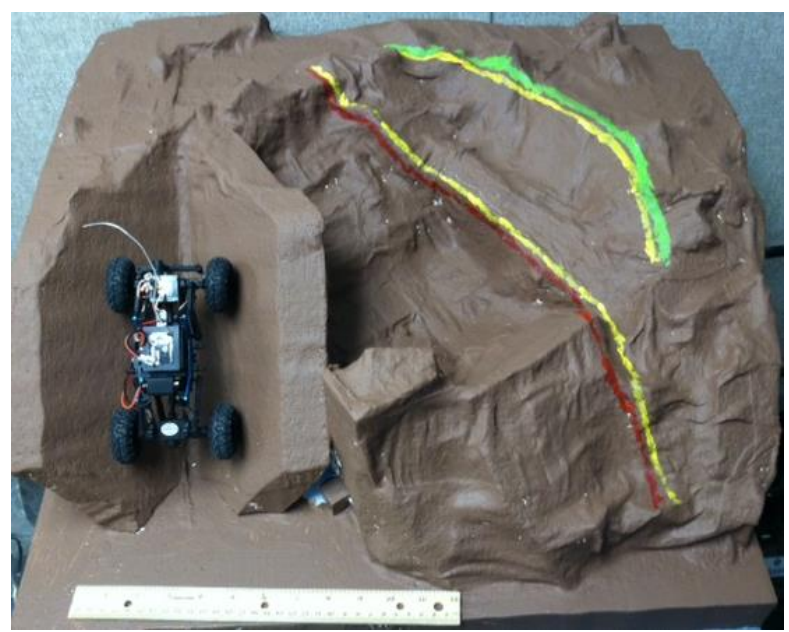

Figure 4: The Mixing Bowl

\section{"Fun" Factor}

The instructional team realized that reminding students to enjoy the opportunity for creativity and competition was important. As such, various ways of building a spirit of fun were brainstormed. A few things which are implemented are the "Rotten Tomatoes" scoring for the video presentations. Additionally, in trying to bring greater attention to the "Cat's Conundrum", campus news featured an article about student accomplishments, and a "picture booth" for team pictures was set up. Additional photographs of the RCVs and other parts of the team's design were also taken with a back drop from the college of engineering.

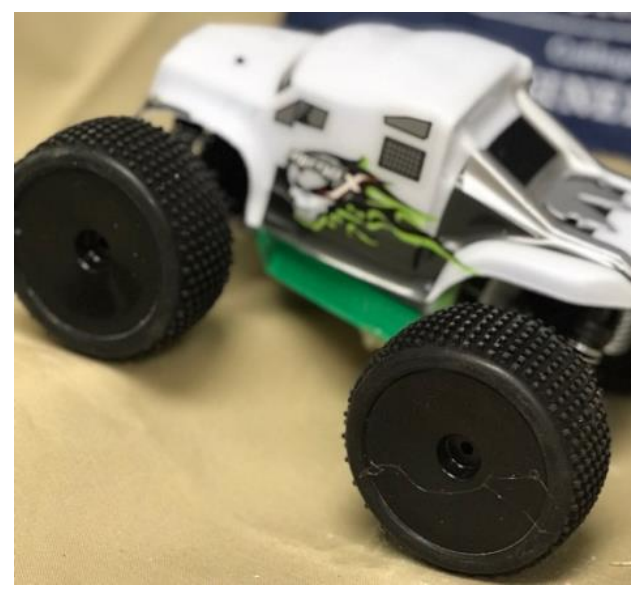

Figure 5: "Cat's Conundrum Photo"

\section{Results from first semester of "Cat's Conundrum"}

Each semester, the assessment process includes most every aspect of the course and the instructors. Student evaluations and feedback from faculty in the departments have indicated a need for a major change in the course such as what has been implemented with "Cat's Conundrum". Course evaluations have indicated significant improvement and were used for 
further changes to the course for Spring 2018. The evaluation process is continuing and will be used for further refinements.

\section{Conclusion}

In conclusion, this paper has presented the process that was used to evaluate, redesign, develop, and implement the junior level multi-d design course into a more effective and successful experience for students. Careful selection of a project that involved all disciplines within our college of engineering was important so that students from different engineering departments had an opportunity for design relevant to their discipline. Furthermore, the redesigned course supports the knowledge base needed for students in their senior capstone course. Additionally, the instructional team realized the importance of providing facilities for students (i.e., Makerspace) to build, test, and evaluate their designs. Finally, the incorporation of "soft skill" development and enhancement for students was a vital concern in selecting a project which could aid in this effort. In redesigning the multi-d engineering course, the instructional team themselves utilized the design process. Initial evaluations for the course have been positive and following the Spring 2018 semester, additional assessments will be done. 


\section{Appendix 1: ABET a-k student outcomes [2]}

(a) an ability to apply knowledge of mathematics, science, and engineering

(b) an ability to design and conduct experiments, as well as to analyze and interpret data

(c) an ability to design a system, component, or process to meet desired needs within realistic constraints such as economic, environmental, social, political, ethical, health and safety, manufacturability, and sustainability

(d) an ability to function on multidisciplinary teams

(e) an ability to identify, formulate, and solve engineering problems

(f) an understanding of professional and ethical responsibility

(g) an ability to communicate effectively

(h) the broad education necessary to understand the impact of engineering solutions in a global, economic, environmental, and societal context

(i) a recognition of the need for, and an ability to engage in life-long learning

(j) a knowledge of contemporary issues

(k) an ability to use the techniques, skills, and modern engineering tools necessary for engineering practice. 


\section{References}

[1] ABET. abet.org

[2] Höpfner, Johannes, Tobias Richter, Peter Košovan, Christian Holm, and Manfred Wilhelm. "Seawater desalination via hydrogels: Practical realisation and first coarse grained simulations." In Intelligent Hydrogels, pp. 247-263. Springer, Cham, Dec. 2013.

[3] Dym, Clive L., Patrick Little, Elizabeth J. Orwin, and Erik Spjut. Engineering design: A project-based introduction. Danvers, MA, USA: John Wiley and Sons, 2009.

[4] Dym, Clive L., Alice M. Agogino, Ozgur Eris, Daniel D. Frey, and Larry J. Leifer. "Engineering design thinking, teaching, and learning." Journal of Engineering Education vol. 94, no. 1, pp. 103-120. Jan. 2005.

[5] Brown, T. and Katz, B., 2011. Change by design. Journal of Product Innovation Management, 28(3), pp.381-383.

[6] Taghavifar, Hamid, and Aref Mardani. "A comparative trend in forecasting ability of artificial neural networks and regressive support vector machine methodologies for energy dissipation modeling of off-road vehicles." Energy vol. 66 pp. 569-576. March 2014.

[7] Posner and Kouzes, A Student Leadership Challenge, Indianapolis, IN: Wiley Publishing, 2014

[8] D2L. d21.com

[9] Trello $\circledR$. trello.com 